\title{
ABUSO DE PODER NAS ELEIÇÕES MUNICIPAIS: uma análise das decisões dos Tribunais Regionais Eleitorais
}

\author{
Leonardo Cajueiro D'Azevedo ${ }^{7}$ \\ Mauro Macedo Campos ${ }^{2}$
}

\section{Palavras-Chave}

justiça eleitoral / eleições municipais / abuso de poder econômico e político / decisões colegiadas / resultado das urnas

\section{SUMÁRIO}

1.Introdução.2.Divisão funcional e espacial de poder no federalismo brasileiro e a regulação das eleições. 3.Abuso de direito e abuso de poder. 3.1.O abuso de direito. 3.1.1.Abuso de direito na legislação brasileira. 3.2.0 abuso de poder. 3.2.1.Abuso de poder eleitoral. 3.3.Abuso de poder na legislação eleitoral. 4.0s abusos de direito e de poder nas eleições municipais. 4.1.Apresentação dos dados nacionais. 4.2.Apresentação dos dados regionalizados. 5.Considerações finais. 6.Referências.

\section{Resumo}

Este artigo analisa os litígios eleitorais nas disputas para os Executivos municipais, entre 1996 a 2012, em todo País. Tem como propósito verificar possíveis congruências das decisões colegiadas dos Tribunais Regionais Eleitorais sobre os abusos de poder econômico e poder político, tendo em vista a falta de um conceito legal sobre o que seria o "abuso de poder" no campo jurídico. A pesquisa buscou identificar e analisar os processos, cujos fatos geradores a Justiça Eleitoral de segunda instância tenha interpretado como sendo abuso de poder político e/ou econômico, em cinco disputas eleitorais para as prefeituras. Os dados foram coletados junto ao Tribunal Superior Eleitoral, que congrega todos os processos registrados nos TRE. Para tanto, foram analisadas as ementas das decisões dos processos encontrados. Apesar de um aumento visível no número de recursos apresentados junto aos tribunais, as análises mostraram que, nas decisões colegiadas, houve uma tendência em negar a existência de abuso de poder nas eleições, mantendo assim, os resultados das urnas. Ou seja, as decisões de primeira instância são, via de regra, prestigiadas pelos respectivos tribunais eleitorais. E quando há confirmação do fato pelo tribunal, há uma predominância do abuso de poder econômico frente ao abuso de poder político.

\footnotetext{
1 Possui mestrado em Sociologia Política pela Universidade Estadual do Norte Fluminense Darcy Ribeiro (2016). Atualmente é doutorando em Sociologia Política pela Universidade Estadual do Norte Fluminense Darcy Ribeiro e professor do Centro Universitário Fluminense. Tem experiência na área de Direito, com ênfase em Direito Eleitoral, atuando principalmente nos seguintes temas: judicialização, abuso de poder, eleições e justiça eleitoral. É juiz de direito no Estado do Rio de Janeiro e exerce a função de Juiz Eleitoral desde 2006.

2 Possui doutorado em Ciência Política pela Universidade Federal de Minas Gerais (2009). Atualmente é professor do Programa de PósGraduação em Sociologia Política da Universidade Estadual do Norte Fluminense Darcy Ribeiro. É também, pesquisador do Laboratório de Estudo da Sociedade Civil e do Estado, da mesma universidade.Tem experiência nas áreas de gestão pública, auditoria e controle, instituições políticas e financiamento partidário-eleitoral.
} 


\title{
ABUSE OF POWER IN LOCAL ELECTIONS: An analysis of the decisions of the Regional Electoral Courts
}

\author{
Leonardo Cajueiro D'Azevedo ${ }^{7}$ \\ Mauro Macedo Campos ${ }^{2}$
}

\section{Key words}

electoral justice / local elections /

abuse of economic and political power /

collegial decisions / result of the ballot box

\section{SUMMARY}

1.Introduction. 2. Functional and spatial division of power in Brazilian federalism and election regulation. 3 . Legal abuse and abuse of power. 3.1.The Legal abuse. 3.1.7. Legal abuse in Brazilian law. 3.2.The abuse of Power. 3.2.1. Abuse of electoral power. 3.3.The abuse of power in electoral law. 4. Abuses of law and power in municipal elections. 4.1.Presentation of national data. 4.2.Presentation of regionalized data. 5. Final considerations. 6.References. aimed to identify and analyze the processes, whichthe Second Instance Electoral Justice has interpreted as abuse of political and/or economic power, in five electoral disputes for municipalities. The data were collected from the Superior Electoral Tribunal, which brings together all the processes registered in the TRE. In order to do so, the decisions of the processes found were analyzed. Despite a visible increase in the number of appeals before the courts, the resultsshowed that in collegiate decisions there was a tendency to deny abuse of power in elections, thus maintaining the results of the ballot box. That is, decisions atfirst instance are, as a rule, presumed by the respective electoral courts. And as there is confirmation of the fact by the court, there is a predominance of abuse of economic power over the abuse of political power.

1 Master's degree in Sociologia Política by Universidade Estadual do Norte Fluminense Darcy Ribeiro (2016). Doctoral student in Political Sociology at the Fluminense North State University Darcy Ribeiro, and a professor at Centro Universitário Fluminense. He has experience in Law, focusing on Electoral Law, acting on the following subjects: judicialization, abuse of power, election and electoral justice. Judge in Rio de Janeiro State and he has served as Electoral Judge since 2006.

2 Doctorate degree in Political Science from the Federal University of Minas Gerais (2009). He is currently is a postgraduate teacher at the Pós-Graduate Program in Political Sociology at Darcy Ribeiro North Fluminense State University. He is also a researcher at the State and Civil Society Studies Laboratory at the same university. Has experience in public management, auditing and control, political institutions and party-electoral financing. 


\section{INTRODUÇÃO}

Este artigo parte da análise dos litígios eleitorais envolvendo denúncias de abuso de poder político e abuso de poder econômico nas eleições municipais em todo País, de modo que se possa observar alguma congruência nas decisões. Forama considerados apenas aqueles que tenham sido objeto de decisão colegiada (Acórdãos) por representarem, em tese, a visão dos Tribunais Regionais Eleitorais (TREs) de cada unidade da federação no período compreendido entre 1996 e 2012, em cinco eleições municipais.

Para o desenvolvimento do texto foram considerados: (i) que a Justiça Eleitoral de segunda instância interpreta o abuso do poder político e o abuso do poder econômi$\mathrm{co}$, de modo que se pudesse identificar "padrões de interpretação" e; (ii) a distribuição geográfica das condenações por abuso de poder em eleições municipais.

A legislação eleitoral faz referência à expressão "abuso de poder" e atribui consequências jurídicas (condenação em multa, declaração de inelegibilidade e cassação do registro da candidatura ou do mandato) àqueles que incidirem em tal prática. Contudo, não há uma descrição sobre o que é abuso de poder, ou quais são os fatos devem ser tratados como de abuso de poder. Tal peculiaridade não é exclusiva do direito eleitoral, outros ramos da ciência jurídica (direito civil, direito processual civil/penal e direito administrativo) também se ocupam do tema sem que haja uma definição legal do que é ou não abuso de poder. Portanto, não há um conceito legal de "abuso de poder" (Di Pietro, 2003; Bandeira de Mello, 2000). Cada ramo do direito procura preencher a lacuna legislativa de acordo com suas especificidades, em matéria eleitoral não é diferente.
É inegável que atribuição da governança das eleições à Justiça Eleitoral de forma concentrada, com as prerrogativas de rule application, rule adjudication e rule making que conferem a este segmento do Judiciário "um enorme poder de atuação no âmbito eleitoral" (Graeff \& Barreto, 2017, pp.100-101). Neste sentido, o artigo prioriza a prerrogativa do "rule adjudication" buscando identificar traços da chamada "judicialização da política" relacionados com as eleições municipais brasileiras, ou por outra, quais desdobramentos decorreram das ações impetradas pela Justiça Eleitoral (Arantes \& Kerche, 1999; Carvalho, 2009). As postulações por parte de candidatos, partidos, coligações e Ministério Público perante a Justiça Eleitoral podem, por um lado, levar a conclusão que a presença direta destes atores na condução das eleições significa judicializar o processo político (Peixinho2008; Sobreiro Neto, 2018), tendo em vista as decisões do Judiciário, apesar das escolhas dos eleitores e da legitimidade dos eleitos. Nessa perspectiva, o Judiciário, com suas decisões, estaria se sobrepondo a soberania do voto popular e modificando a composição dos demais poderes da república. Por outro, pode também representar uma "garantia" de respeito às regras do jogo eleitoral em consideração aos eleitores/cidadãos, como aos próprios atores políticos, no que se refere aos abusos de poder político e econômico, comumente divulgado pela mídia, em todo o País. Esse antagonismo é ilustrado por Souza (2017, p.73) por meio da contraposição dos princípios eleitorais "uma pessoa, um voto" e "eleições livres".

Muitas das questões que são levadas ao Judiciário poderiam ser solucionadas na própria seara política. Para o que se pretende neste artigo, a chamada "judicialização" das 
disputas eleitorais representa apenas mais uma arena típica do pluralismo democrático e seu caráter conflituoso.

O enfrentamento de questões eleitorais vem sendo tratado nas ciências sociais em função da legitimidade dos eleitos (Silva, 2012; Marchetti \& Cortez, 2009) passando ao largo da ideia de Estado de direito e da legalidade no exercício do poder político (Schedler, 1999). Dentro dos limites do tema proposto, o objetivo aqui é identificar as fontes jurídico -históricas do abuso de poder eleitoral e reconhecer padrões nos julgamentos dos TREs que tratem de abuso de poder em eleições municipais. Dessa forma, busca-se aclarar os critérios dos TREs na fixação e julgamento de casos de abuso de poder para estas eleições.

As eleições brasileiras, a partir dos últimos pleitos passaram a contar o componente da judicialização. Isto é, independentemente do resultado das urnas, a propositura de ações perante a justiça eleitoral podem influenciar no resultado final das eleições. Com efeito, diversos candidatos eleitos foram afastados de modo provisório ou definitivo do exercício de suas funções. E neste contexto, os estudos sobre as eleições municipais ganharam destaque. Em boa medida, as análises se concentram sobre os resultados eleitorais e a distribuição dos partidos políticos nos municípios. Todavia, o papel que o Poder Judiciário exerce nas eleições locais ainda é carente de aprofundamentos, sobretudo no que tange às "interferências diretas" na condução do processo eleitoral pelos Tribunais. Este artigo busca contribuir nessa direção.

\section{DIVISÃO FUNCIONAL E ESPACIAL DE PODER NO FEDERALISMO BRASILEIRO E A REGULAÇÃO DAS ELEIÇÕES}

O Brasil tem a característica de possuir órgãos judiciários da União Federal em paralelo com a existência e funcionamento de Justiças Estaduais. O sistema judicial federal tem a peculiaridade de se subdividir em diversas "justiças" especializadas por matéria 3 (Militar, Eleitoral, Trabalhista e Federal). No que se refere à Justiça Eleitoral, a Constituição prevê a existência de um órgão de cúpula (Tribunal Superior Eleitoral), órgãos máximos em cada Estado da Federação (Tribunais Regionais Eleitorais),

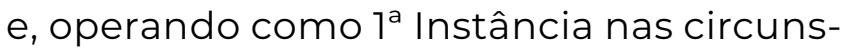
crições eleitorais tem-se os Juízes Eleitorais e as respectivas Juntas Eleitorais. Ainda assim, a Justiça Eleitoral brasileira acumula funções que vão além do exercício da jurisdição, da solução de litígios eleitorais, operando como organizadora e administradora do processo eleitoral (responsabilizando-se pelo alistamento de eleitores, registro de candidatos, logística e preparação da votação, apuração, etc.), e ainda como órgão de consulta e órgão normativo.

No intuito de descrever o funcionamento do judiciário eleitoral cabe apontar a composição dos quadros da Justiça Eleitoral, uma vez que é a única em que há toda uma previsão de órgãos e funções, mas não há um quadro próprio de magistrados. Isto é, a Justiça Eleitoral brasileira funciona com magistrados "emprestados" de outras carreiras. Para melhor ilustrar a composição "por empréstimo" da Justiça Eleitoral no Brasil, organizamos o quadro 1.

3 Cada ramificação das "justiças" federais possui toda uma estrutura funcional e administrativa próprias, com quadro próprio de magis trados e servidores auxiliares, exceto na justiça eleitoral. Em razão da especialidade por matéria, cada uma das "justiças" possui uma competência constitucional própria. 
Quadro 1: Cargos, composição, área de atuação e composição dos órgãos da justiça eleitoral.

\begin{tabular}{|c|c|c|c|}
\hline Órgão & Funcionamento & Jurisdição & Composição \\
\hline $\begin{array}{l}\text { Tribunal Superior } \\
\text { Eleitoral (TSE) }\end{array}$ & $\begin{array}{l}\text { Colegiado } \\
\text { (7integrantes) }\end{array}$ & $\begin{array}{l}\text { Todo território } \\
\text { nacional }\end{array}$ & $\begin{array}{l}3 \text { magistrados do Supremo Tribunal Federal (STF) } \\
2 \text { magistrados do Superior Tribunal de Justiça (STJ) } \\
2 \text { advogados nomeados pelo Presidente da República, den- } \\
\text { tre 6previamente indicados pelo STF. }\end{array}$ \\
\hline $\begin{array}{l}\text { Tribunais Regionais } \\
\text { Eleitorais (TREs) }\end{array}$ & $\begin{array}{l}\text { Colegiado } \\
\text { (7 integrantes) }\end{array}$ & $\begin{array}{l}\text { Território da } \\
\text { respectiva uni- } \\
\text { dade da fede- } \\
\text { ração. }\end{array}$ & $\begin{array}{l}2 \text { magistrados da } 2^{a} \text { Instância (Tribunais de Justiça) da UF; } \\
2 \text { magistrados de } 1^{a} \text { Instância da UF; } \\
1 \text { magistrado federal da } 2^{a} \text { Instância da UF; } \\
2 \text { advogados nomeados pelo Presidente da República, den- } \\
\text { tre } 6 \text { previamente indicados pelo Tribunal de Justiça da UF. }\end{array}$ \\
\hline Juízes Eleitorais & $\begin{array}{l}\text { Singular } \\
\text { (1 integrante por } \\
\text { circunscrição } \\
\text { eleitoral) }\end{array}$ & $\begin{array}{l}\text { Território da } \\
\text { circunscrição } \\
\text { eleitoral. }\end{array}$ & $\begin{array}{l}\text { Magistrado estadual de } 1^{a} \text { Instância em exercício no territó- } \\
\text { rio da circunscrição eleitoral. } \\
\text { (Havendo mais de } 1 \text { juiz estadual no território da circunscri- } \\
\text { ção eleitoral é obrigatório o rodízio entre eles a cada } 2 \text { anos) }\end{array}$ \\
\hline
\end{tabular}

Fonte: Elaborado pelos autores.

Em termos formais, a existência de um "Código Eleitoral", anterior à promulgação da Constituição de 1988 (e a legislação subsequente), teve o seu papel reduzido. O Código redigido sob a égide de um regime autoritário é, em grande parte, incompatível com a nova ordem constitucional e obsoleto ao ignorar os avanços tecnológicos ocorridos desde sua promulgação.

A Lei das Eleições trata das questões práticas relacionadas com o pleito. Se o Código Eleitoral foi esvaziado pela Constituição no que tange a previsão de direitos políticos, organização e funcionamento da Justiça Eleitoral, aqui, a nova legislação derrogou o código no que ser refere às coligações, convenções, registro de candidaturas, financiamento de campanhas, pesquisas e propagandas eleitorais. A Lei dos Partidos Políticos, como o próprio nome sugere, trata da criação e funcionamento das agremiações partidárias. Mais importante para este artigo é a Lei Complementar n 64 de 1990, conhecida como "lei das inelegibilidades", em razão de condenação pela prática de abuso de poder político ou econômico.

\section{ABUSO DE DIREITO E ABUSO DE PODER}

O conceito de poder em Max Weber no sentido de que corresponde à "probabilidade de impor a própria vontade dentro de uma relação social, mesmo contra toda a resistência e qualquer que seja o fundamento dessa probabilidade" (Quintaneiro; Barbosa \& Oliveira 2003, p.119) não foi a premissa legislativa. Weber (2005) trata do poder de fato, presente em todas as relações sociais, a legislação eleitoral, por sua vez, trata do poder de agir durante a campanha eleitoral.

Este poder de agir nas disputas eleitorais nas quais partidos, coligações e candidatos competem pelo voto do eleitor é normatizado e possui características próprias, sendo a principal delas o seu caráter limitado e condicionado. No entanto, não há plenos poderes. As possibilidades de agir permitidas são limitadas, seja pelo que o Estado autorizou ou proibiu, seja pelo conjunto de direitos e garantias que outros atores (candidatos, partidos, coligações e eleitores) possuem. A competição dos atores políticos 
pelo voto corresponde às possibilidades de atuação reguladas pelas normas estabelecidas. Nas subseções que seguem trataremos da natureza do abuso de poder referido pela legislação eleitoral e suas conexões com as noções de abuso de direito e abuso de poder, existentes na ordem jurídica.

\subsection{O ABUSO DE DIREITO}

Por abuso entende-se o mau uso, ou o desdobramento do uso, a ultrapassagem dos limites de uso normal. Estaremos diante de abuso sempre que uma ação se revelar irrazoável ou anormal. O cerne da noção é que nos atos abusivos "ultrapassa-se o padrão normal de comportamento, realizando-se condutas que não guardam relação lógica com o que normalmente ocorreria ou se esperaria que ocorresse" (Gomes 2012, p.220). O entendimento básico deste termo para o direito é aqui, um ponto de partida.

A ideia de direito subjetivo constitui uma das categorias básicas para o meio jurídico. Sua exata conceituação envolve um dos maiores debates teóricos da comunidade do direito. Todavia, para o este artigo é desnecessário apontar todas as correntes teóricas. Nos importa apenas a noção de direito subjetivo para, em seguida, apontar como o direito subjetivo se relaciona com a teoria do abuso de direito. A ordem jurídica prevê uma série de normas que conferem direitos ao cidadão. O conjunto de normas, o direito posto e imposto pelo Estado é conhecido como direito objetivo. Tais direitos quando titularizados por uma pessoa determinada são denominados direitos subjetivos. Para este artigo nos valemos do entendimento do direito subjetivo como "o poder que a ordem jurídica confere a alguém de agir e de exigir de outrem determinado comportamento" (Amaral 2006, p.188). Essa noção envolve a proteção de um determinado interesse ou comportamento pela norma de direito (Abdo, 2007). Porém, somente com a perspectiva de que direitos subjetivos são relativos é que podemos trabalhar com o seu exercício regular ou abusivo.

\subsubsection{ABUSO DE DIREITO NA LEGISLAÇÃO BRASILEIRA}

O direito brasileiro admitiu com facilidade a ideia de abuso de direito desde a vigência de nosso primeiro Código Civil, em 1916 mesmo na ausência de previsão legal expressa em tal sentido. O raciocínio que se fazia, até então, estabelecia que se não é ilícito o ato praticado no exercício regular de um direito, em sentido contrário, será ilícito o ato praticado no exercício irregular de um direito. Com tal interpretação o abuso de direito foi admitido sem maiores questionamentos, havendo debate tão somente quanto aos critérios para seu reconhecimento: teorias subjetiva ou objetiva (Pereira, 1998; Beviláqua, 1976).

Vale dizer que a discussão sobre os critérios para apreciação do abuso de direito (ou do exercício abusivo de direitos) envolve a exigência ou não da intencionalidade como elemento necessário ao ato abusivo. O critério subjetivo (teorias subjetivas) exige a intenção, já o critério objetivo (teoria objetiva) dela prescinde (Stoco, 2002). Portanto, aqui, o elemento intencional é imprescindível, evidenciando-se pela ausência de proveito ou utilidade na prática do ato em favor de quem o praticou (Abdo, 2007).

A orientação objetiva dispensa o elemento intencional e analisa o ato sob a perspecti- 
va do desatendimento dos fins econômicos e sociais da lei. Nesta orientação o que importa é analisar se no ato houve desvio de finalidade em relação ao que a lei estabeleceu. Portanto, a construção do instituto do abuso de direito ocorreu no âmbito das relações entre particulares e envolveu o exercício abusivo de uma posição jurídica, isto é, amparada pelo direito, de modo abusivo, contrário às finalidades sociais da lei. Para este artigo o que importa é o registro de toda uma construção teórica e prática que nega a possibilidade de exercício absoluto de direitos e de que limita o exercício às finalidades sociais da lei.

\subsection{O ABUSO DE PODER}

A consolidação do moderno Estado de Direito trouxe prerrogativas que podem ser vistas como poderes os quais a administração pública, o poder público, agentes públicos, possuem para atingir os fins atribuídos ao Estado pela Constituição e as leis. A teoria do abuso de poder está intimamente ligada à noção de Estado de Direito e legalidade nos atos do Estado. Essa característica fez com que a admissibilidade do instituto fosse menos controversa, sem maiores atropelos teóricos. O desenho institucional de Estado previsto pela ordem jurídica confe- re àquele, prerrogativas, poderes, possibilidades de agir, que não são conferidas aos particulares e que podem ser empregadas contra quem se opor ao desejo estatal (Meirelles, 2011; Yamaguti Sato, 2018).

Todas as determinações impostas correspondem aos limites legais de quem exerce tais poderes com o propósito de evitar arbitrariedades. Sem prejuízo do que já foi exposto, não se pode negar que a teoria do abuso de direito influenciou a teoria do abuso de poder, havendo referência entre os autores estudados de que tal instituto não é senão uma modalidade de "abuso de direito" ou a expressão desse vício na esfera pública (Bandeira de Mello, 1969). Se o abuso de direito se presta a coibir arbitrariedades nas relações privadas, o abuso de poder o faz nas relações entre Estado e particular. Portanto, quando tratamos de abuso de poder estamos diante de situações em que o agente atua fora dos limites estabelecidos na lei (excesso de poder) ou quando, ainda que esteja dentro de tais limites, afasta-se da finalidade exigida na lei de modo explícito ou implícito (desvio de finalidade). Não podendo passar despercebido que a noção de abuso de poder sempre deverá estar atrelada ao exercício de função ou atividade pública com prerrogativas de poder estatal. A figura 1 traz a classificação adotada neste artigo.

Figura 1: Classificação do abuso de poder no âmbito do desrespeito à lei

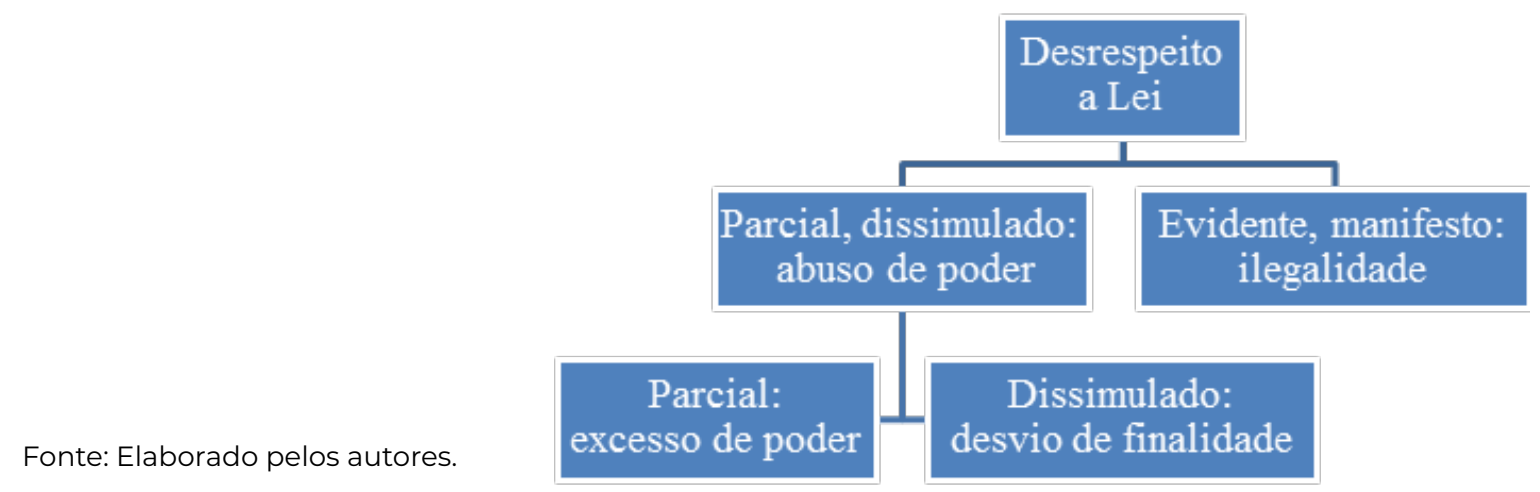


Do que foi exposto, a construção do instituto do abuso de poder se dá no âmbito das relações entre a autoridade pública e particulares e envolve o exercício abusivo das prerrogativas estatais, seja extrapolando limites, seja contrariando a finalidades da lei. Portanto, quando tratamos de abuso de poder estamos diante de situações em que o agente atua fora dos limites estabelecidos na lei (excesso de poder) ou quando, ainda que esteja dentro de tais limites, afasta-se da finalidade exigida na lei (desvio de finalidade). Não podendo passar despercebido que a noção de abuso de poder sempre deverá estar atrelada ao exercício de função ou atividade pública com prerrogativas de poder estatal.

\subsubsection{ABUSO DE PODER ELEITORAL}

A existência de um conjunto de normas disciplinando o processo eleitoral, atribuindo consequências legais para os casos de abuso de poder, resulta do significado social atribuído ao voto no processo de escolha dos representantes dos Poderes Executivo e Legislativo. Em outras palavras, a retidão e a igualdade de competição constituem valores sociais relevantes, a ponto de serem normatizados e impostos aos competidores eleitorais (Arantes \& Kerche, 1999; Reale, 2009; Yamaguti Sato, 2018).

No enfrentamento do abuso de poder nas eleições é preciso ter atenção a categoria weberiana da ação racional, entendendo-a como aquele produto da razão humana direcionada a fins ou valores de modo a distinguir o que move os atores eleitorais (competidores e reguladores) (Marchetti \& Cortez, 2009). A ação racional com relação a fins é determinada pela expectativa de atingir uma determinada finalidade racionalmente avaliada, desejada e perseguida. Com relação a valores é aquela definida pela adesão consciente no valor (ético, estético, religioso, etc.) (Weber, 2005). No que tange aos competidores eleitorais (partidos, coligações e candidatos) sua ação deve ser compreendida como racional em relação aos fins.

Quanto aos reguladores eleitorais (Poder Judiciário e Ministério Público), dentro da classificação weberiana, sua ação deve também ser considerada como racional em relação a valores, orientando-se por princípios contidos na legislação. A distinção é relevante na percepção do que move os atores eleitorais quando demanda da máquina judiciária o reconhecimento do abuso de poder nas eleições. A figura 2 representa esta classificação.

\section{Figura 2. Classificação dos atores eleitorais segundo sua ação racional}

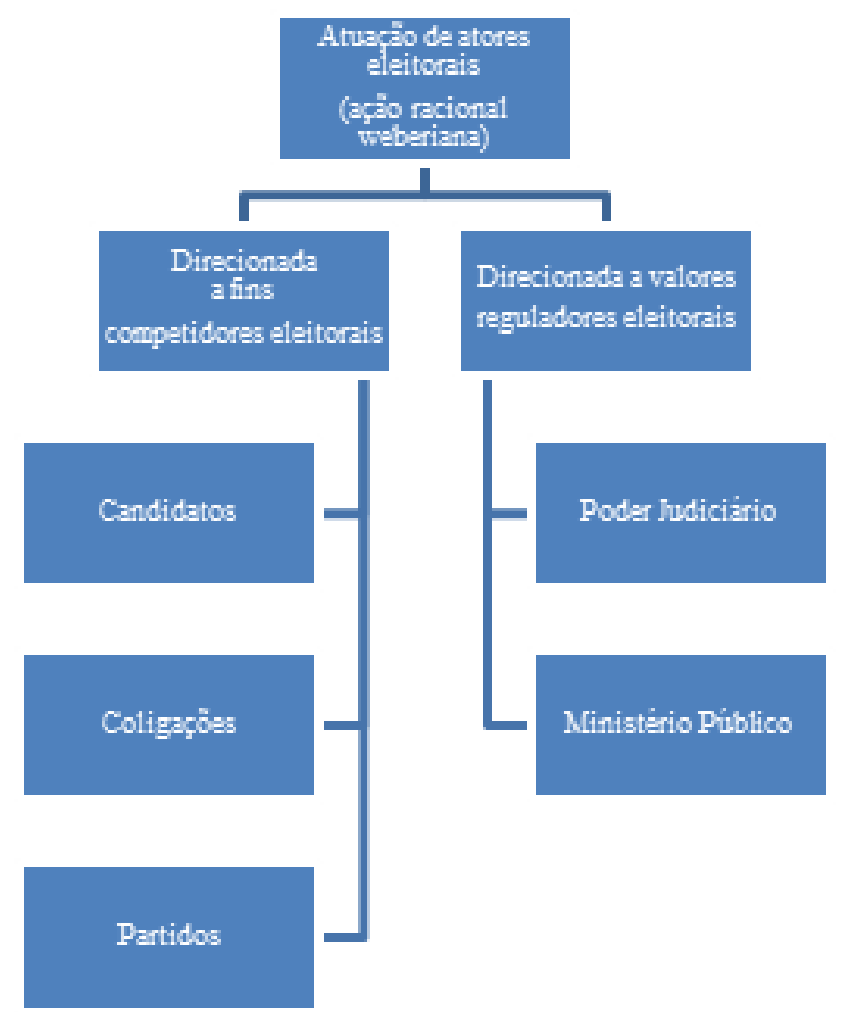

Fonte: Elaborado pelos autores. 
Até aqui o essencial é perceber que o exercício de posições jurídicas, sejam direitos subjetivos ou prerrogativas estatais, no que concerne às eleições, é normatizado e possui características próprias, sendo a principal delas o seu caráter limitado e condicionado. Não há pleno exercício de direitos subjetivos ou de prerrogativas estatais em matéria eleitoral.

Quando tratamos especificamente de abuso de poder nas eleições, ao confrontá-lo com o delineio jurídico dos institutos do abuso de direito e abuso de poder, percebemos que,na verdade, a legislação abriga sob o mesmo rótulo "abuso de poder" as categorias do abuso de direito e abuso de poder. As ações em campanhas eleitorais constituem exercício de direitos políticos e, quando se pratica um abuso de poder, está-se na verdade, em alguns casos abusando do direito de competir pela preferência dos eleitores (abuso de direito) e em outros abusando das prerrogativas inerentes a função pública (abuso de poder).

\subsection{ABUSO DE PODER NA LEGISLAÇÃO ELEITORAL}

É inegável que o poder econômico e o poder político influenciam o processo eletivo. Não se pode simplesmente excluí-los do jogo político. São fatos sociologicamente apreendidos (Capeller, 2015), correspondendo ao resultado das relações sociais existentes e do sistema econômico (Speck, 2002; Costa, 2006; Peixoto, 2010; Mancuso, 2015). Diante do fato, o legislador brasileiro tratou sobre o tema em diversos textos legislativos, estabelecendo um conjunto de normas disciplinando o processo eleitoral e atribuindo consequências legais para os casos de abuso de poder, sendo resultado do especial significado social atribuído à higidez no processo de escolha dos representantes dos Poderes Executivo e Legislativo. Neste sentido, o direito eleitoral brasileiro tem por desafio garantir instrumentos eficazes para refrear o abuso de poder nas eleições. Uma atribuição nada simples, pois a cada nova regulação há sempre a conformação de novas formas de agir e que impactam em comportamentos oportunistas (Figueiredo Filho, 2012).

Em termos da trajetória normativa sobre essa temática, o Código Eleitoral brasileiro, em 1965, já previa a coibição e a punição da interferência do poder econômico e o desvio ou abuso de poder de autoridade contrários a liberdade do voto. Todavia, o Código praticamente não é mais aplicado por ter sido revogado tacitamente pela legislação posterior a Constituição. Percebe-se que a própria redação legislativa nos idos de 1965, ou mesmo no já distante ano de 1988, sugere que a prática abusiva é uma realidade, algo negativo que existe e precisa ser combatido.

Na Lei das Eleições (Lei n 9.504, de 1997), que como próprio nome sugere tem o objetivo de regulamentar o processo eletivo, nos deparamos com três referências ao abuso. A primeira delas trata de abuso de poder econômico relacionado ao financiamento de campanhas que, eventualmente comprovado acarretará o cancelamento do registro de candidatura e, caso já eleito, acarretará a perda do mandato. A segunda referência estabelece que realizar publicidade institucional de um governo transformando-a em propaganda do governante de ocasião constitui abuso de autoridade, atribuindo a consequência de cancelar o registro da candidatura ou, caso já finalizada a eleição, o cancelamento do diploma ${ }^{4}$. A última envolve a extrapolação nos limites de gastos em campanha eleitoral e sujeita o candidato beneficiado a persecu-

4 postulante a cargo eletivo no Brasil passa pelas condiç̃os: candidato, diplomado e empossado. Começa ao ter a candidatura admitida. Caso vença as eleições a Justiça Eleitoral o transforma em candidato diplomado. Por fim é empossado e inicia o seu mandato. Portanto, são três atos distintos: registro, diplomação e posse. Caso esteja empossado o cancelamento do diploma implica a perda do mandato. 
ção judicial por abuso de poder econômico.

Um pouco antes, nessa mesma década, a Lei Complementar n 64 de 1990, conhecida como Lei das Inelegibilidades, faz referência ao abuso (seja político ou econômico) em 13 oportunidades. Para o que se pretende neste artigo abordaremos apenas aquele que se considera mais relevantes. $O$ artigo $1^{\circ}$ estabelece que todos os que tenham contra si condenação transitada em julgado ou condenação por órgão colegiado da justiça eleitoral são inelegíveis para qualquer cargo eletivo e, ainda considera inelegível todo aquele condenado por crime de abuso de autoridade, também pelo mesmo prazo sempre que a sentença impuser a perda do cargo ou inabilitação para o exercício de função pública. Neste mesmo artigo há também referência ao abuso de poder, tornando inelegíveis todos os detentores de cargos na administração pública que tenham se beneficiado ou a terceiros mediante abuso de poder político ou econômico.

Como se percebe a legislação eleitoral faz referência à expressão "abuso de poder" e atribui consequências jurídicas àqueles que incidirem em tal prática. Contudo, a legislação não descreve o que é abuso de poder ou quais são os fatos que se subsumem ao conceito de abuso de poder. Portanto, não há um conceito legal de "abuso de poder". A lacuna legislativa não interessa apenas ao universo jurídico, uma vez que o correto entendimento do que é abuso de poder em eleições constituirá um marco de fato e de direito para disputas eletivas. $O$ elemento complicador é que em razão da falta de conceito legal, já que a norma sequer define os fatos que constituem abuso, tem sido o Judiciário, caso a caso, o intérprete da atuação dos partidos, coligações e candidatos se ela ocorreu dentro do espaço de licitude "previsto" na norma. Entretanto, dada a peculiaridade da investidura por mandato nos Tribunais Regionais Eleitorais e no Tribunal Superior Eleitoral não há linearidade de entendimentos em determinado sentido, estando os precedentes sujeitos a variação na mesma proporção que a modificação da composição das cortes eleitorais.

O tema do abuso de poder em matéria eleitoral ainda padece de sistematização, sendo que a própria Justiça Eleitoral possui um glossário para consulta pública na internet 5 . Daí a importância de encontrar alguma parametrização nos casos estudados.

A partir do breve desenho teórico aqui apresentado, para constatação do abuso de direito, basta somente a análise se o exercício se deu conforme o espaço de licitude concedido pela norma (Rodovalho, 2011, p.170). Entretanto, até o advento da inclusão pela Lei Complementar 135/2010, um determinado fato tido por abusivo (além do seu uso normal) repercutia efetivamente ou potencialmente na disputa política. Tal repercussão em alguns casos era exigida pelos tribunais para que se reconhecesse um fato como abusivo. Havia também decisões que exigiam tão somente a "potencialidade" do fato abusivo repercutir na lisura das eleições (Castro, 2012, p.340), o que só gerava mais confusão.

Com a finalidade de tentar aclarar o instituto do abuso de poder em matéria eleitoral, tais requisitos foram expressamente dispensados pela LC135/2010, passando a dispor peremptoriamente que, para a configuração do ato abusivo, não seria mais considerada a potencialidade de o fato alterar o resultado da eleição, mas apenas a gravidade das circunstâncias que o caracterizam. Não é di- 
fícil notar que a investidura temporária nos tribunais eleitorais impede, ou em muito dificulta, a formação de decisões reiteradas no mesmo sentido. Portanto, esvazia a utilidade dos precedentes quando isoladamente considerados. A prática da simples enumeração feita por alguns autores, se por um lado não põe termo as dúvidas sobre o que deve ser considerado abuso de poder em matéria eleitoral, ao menos se presta a fazer um recorte temporal e geográfico, além de servir de indício para uma possível interpretação futura (dada a instabilidade na composição dos tribunais eleitorais) e, eventualmente, poder contribuir para ordenar tais questões e apontar tipologias possíveis das decisões do judiciário sobre esta temática.

A legislação eleitoral emprega, sem técnica ou critérios, a expressão, abuso de poder, ora podendo se referir ao abuso de direito, ao abuso de poder ou até mesmo ao abuso de autoridade. Intencional, ou não, o modelo legislativo confunde os atores políticos e dificulta a regulação das disputas eleitorais. A dificuldade que se impõe é que a própria noção de abuso de direito é fluída, difusa e carente de uma definição mais certeira. $O$ mesmo ocorre nos casos de abuso de poder por desvio de finalidade. Portanto, dependem do caso concreto. A forma pela qual a LC 64/1990 trata o abuso nas eleições o aproxima em grande parte das noções de abuso de direito e abuso de poder expostas neste estudo. Talvez esteja aí a fonte da ausência de tipificação legal das hipóteses de abuso, restando ao aplicador da lei e aos envolvidos na disputa política se socorrerem de elementos diversos para análise da abusividade ou não dos atos praticados nas campanhas eleitorais.

Há, portanto, uma dificuldade em elaborar uma fórmula precisa, restando reconhecer que "o abuso de poder constitui conceito jurídico indeterminado, fluído e aberto, cuja delimitação semântica só pode ser feita na prática, diante das circunstâncias que o evento apresentar" (Gomes, 2012, pp.253254). Essa condição torna necessário um esforço na via interpretativa para acomodar as finalidades abstratamente previstas na lei com a realidade no qual ela é aplicada (com os seus matizes culturais, sociais, éticas, etc.). O que não se pode perder de vista é que diante de uma cláusula aberta, um conceito jurídico indeterminado, ao interpretá-los, enquanto limitador do exercício de direitos, não se pode ser arbitrário.

Ao tratar da teoria do abuso de direito, Rodovalho (2011, p.132) afirma que a "concepção de interpretação não pode ser individualista ao ponto de negar ou enfraquecer o Estado, nem opressora aponto de negar ou destruir o indivíduo". Trazendo a ideia para seara eleitoral podemos dizer que na interpretação das condutas ditas abusivas não pode ser individualista ao ponto de enfraquecer a regulação das eleições nem opressor ao ponto de inviabilizar candidaturas.

O exercício de direitos subjetivos relativos à disputa eleitoral deve ser praticado até o limite do justificável pelos fins da própria norma que legitima a prática do ato. $\bigcirc$ agir conforme a lei não abarca todos os desejos e pretensões possíveis, mas somente aqueles que estão em conformidade com o ordenamento jurídico. O mesmo vale na corrida eleitoral. Quando o exercício de um direito se afasta de sua função social afasta-se do direito como um todo e transforma-se em abuso.

A interpretação dos atos praticados durante as eleições e sua definição como abusivos exige uma análise do todo, compreendendo 
o direito como algo uno e aplicá-lo segundo as finalidades previstas na lei, sempre atento a realidade social e política que cerca sua aplicação quando da definição no caso concreto se houve ou não abuso'. A legislação em geral exige cada vez mais que a sua interpretação leve em consideração a realidade que cerca sua aplicação. Tal fenômeno vem ocorrendo não apenas em matéria eleitoral, tendo em vista disposições semelhantes na lei que trata de litígios de menor complexidade $^{7}$ e no Código de Processo Civil ${ }^{8}$.

Não bastassem comandos legais expressos para considerar questões circunstanciais na análise dos fatos abusivos, o STF levou em conta questões meta-jurídicas (Jorge \& Soares, 2017, p.91) para considerar inconstitucionais ${ }^{9}$ dispositivos contidos na Lei dos Partidos Políticos (Lei 9.096/1995) e na Lei das Eleições (Lei 9.504/1997) que permitiam a realização de doações eleitorais por pessoas jurídicas. Muito embora o abuso de poder não tenha sido o tema central de debate no STF, diversos autores, tanto no campo do direito, bem como da sociologia e ciência política apontam que o dinheiro pode desequilibrar a balança da competição eleitoral (Almeida (2018; Heiler, 2018; Jorge \& Lizardo, 2018).

Estudiosos do assunto procuram associar o abuso do poder econômico ao mau uso de recursos financeiros ou patrimoniais para

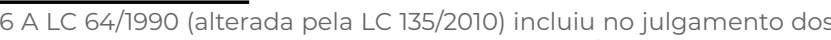
casos de abuso a seguinte previsão: "O Tribunal formará sua convic ção pela livre apreciação dos fatos públicos e notórios, dos indícios e presunções e prova produzida, atentando para circunstâncias ou fatos, ainda que não indicados ou alegados pelas partes, mas que preservem o interesse público de lisura eleitoral" (Art. 23).
}

7 Lei 9.099/95, "Art. $5^{\circ} \mathrm{O}$ juiz dirigirá o processo com liberdade para determinar as provas a serem produzidas, para apreciá-las e para da especial valor às regras de experiência comum ou técnica" e "Art. $6^{\circ} \mathrm{O}$ juiz adotará em cada caso a decisão que reputar mais justa e equânime, atendendo aos fins sociais da lei e às exigências do bem comum".

8 Ver art. 375 da Lei 13.105/2015, o qual estabelece que o juiz aplicará as regras de experiência comum subministradas pela observação do que ordinariamente acontece e, ainda, as regras de experiência técnica, ressalvado, quanto a estas, o exame pericial (grifo nosso).

9 Ação direta de inconstitucionalidade $n^{0}$ 4.650/DF (Brasil, 2016) influenciar o exercício do voto de modo a provocar desdobramentos na eleição atual ou futura. O abuso do poder político, por seu turno, é associado ao emprego da máquina pública ao serviço de um candidato.

Em termos de política legislativa, a opção brasileira de não definir expressamente os casos de abuso de poder possui vantagens e desvantagens. A principal vantagem está na desnecessidade de constantes mudanças legislativas para conceituar ou definir o "abuso de poder" permitindo que o Judiciário integre o significado do texto legal ao longo do tempo. De certo modo, o legislador reconhece a impossibilidade material de antecipar previamente quais comportamentos podem ou não ser considerados abusivos. Neste sentido, ressaltam-se as dificuldades da elaboração de uma normativa prévia aos fatos. Exemplo desse imbróglio, somente em tempos recentes passou-se a refletir sobre o abuso de poder religioso e sua influência deletéria no processo político em um Estado laico (Strücker \& Maçalai, 2019). Já no tocante à desvantagem podemos destacar certo grau de insegurança jurídica para os envolvidos no processo eleitoral que não possuem meios de saber antecipadamente quais condutas devem ser evitadas, prevenindo-se da impugnação de mandatos conquistados e a subsequente cassação.

Na última seção deste artigo trataremos dos dados específicos da pesquisa. Depois do rápido sobrevôo sobre os impasses na literatura específica os entendimentos relativos aos chamados "abusos de poder nas eleições" e a sua aplicação nos casos, partimos para as análises das decisões colegiadas relativas ao tema na ótica dos TREs. 


\section{OS ABUSOS DE DIREITO E DE PODER NAS ELEIÇÕES MUNICIPAIS}

A construção dos dados para este artigo contou com uma amostra delimitada pelo conjunto de precedentes dos Tribunais Regionais Eleitorais (TREs) envolvendo abuso de poder em eleições municipais. De início, buscou-se somente decisões colegiadas em grau de recurso em Ações de Investigação Judicial Eleitoral (AIJEs) e Ações de Impugnação de Mandato Eletivo (AIMEs) ou aquelas apreciadas originariamente pelos TREs que tenham entrado ou não no mérito sobre a existência do abuso de poder. Porém, quando do levantamento dos dados nos deparamos com uma diversidade de ações e recursos objeto de análise pelos tribunais e os incluímos na base pesquisada.

De todo modo, o que interessa como dado primário é avaliar se uma ação que trate da possível ocorrência de abuso de poder em eleições municipais teve resposta positiva ou não, por parte dos TREs. Neste último caso estão englobadas as hipóteses de negativa pela análise do fato em si e aquelas que por alguma questão processual sequer foram analisadas. O recorte temporal refere-se às eleições municipais de 1996, 2000, 2004, 2008 e 2012. Os dados das últimas eleições municipais de 2016 não foram considerados pelo fato de os dados não estarem compilados até a confecção deste artigo.

Durante a análise de dados contabilizamos o número de ações julgadas e sua variação no tempo. Apontamos a categoria dos atos reconhecidos como abusivos e verificamos se houve confirmação ou modificação da decisão de $1^{a}$ Instância, proferidas pelos juízes eleitorais. Como instrumento de coleta de dados, usamos o sistema informatizado do Tribunal Superior Eleitoral para pesquisa de processos, disponibilizado para consulta pública disponível através da internet.

\subsection{APRESENTAÇÃO DOS DADOS NACIONAIS}

Para darmos alinhamento empírico para a proposta desse artigo, começamos pelo levantamento dos precedentes perante os TREs de todas as unidades da federação por meio do sistema informatizado do TSE, obtidos com o seguinte argumento de pesquisa10: "abuso de poder" (+) "eleições municipais", desconsiderando-se decisões monocráticas dos tribunais.

É importante destacar que a base de dados pesquisada sofre alterações, algumas delas esperadas como o aumento do número de casos com o passar do tempo, na medida em que são incluídos na base. Entretanto, durante nas consultas realizadas, percebeuse em algumas ocasiões, a busca efetuada junto ao sistema retornar resultados a menor. Portanto, uma resposta em sentido contrário ao esperado.

Outro ponto relevante acerca da base de dados disponível para consulta é que não há uniformização de critérios para indexação (keywords) dos julgados, estando sujeito ao alvedrio da pessoa que insere as palavraschave para pesquisa, variando de tribunal para tribunal e mesmo de pessoa para pessoa dentro da mesma Corte. São apontamentos que evidenciam a complexidade das pesquisas que lidam com essa base de dados, bem como apontam as fragilidades do próprio sistema do Tribunal. Tais dificuldades em relação a estes dados também foram encontradas por Vitor Marchetti (2014, pp.96-97), ao analisar o "cancelamento de 
registro de candidatos e cassação de mandatos" em eleições municipais e gerais, de 1990 a 2004. O autor chama atenção para o fato de que "o sistema de catalogação e publicações das decisões do TSE é bastante precário". Essa dificuldade, embora traga contratempos para o levantamento dos dados, não invalida os resultados obtidos, uma vez que foram objeto de análise ao longo do trabalho. Os resultados obtidos foram consolidados na tabela $1 \mathrm{com}$ os totais de precedentes por TRE.

Tabela 1: Número de processos analisados por Estado da Federação.

\begin{tabular}{|c|c|c|c|}
\hline & Frequência & $\%$ & $\%$ Acumulado \\
\hline $\mathrm{AL}$ & 2 & 1,3 & 1,3 \\
\hline AM & 2 & 1,3 & 2,6 \\
\hline$A P$ & 3 & 2,0 & 4,6 \\
\hline BA & 1 & 0,7 & 5,3 \\
\hline$C E$ & 2 & 1,3 & 6,6 \\
\hline ES & 3 & 2,0 & 8,6 \\
\hline GO & 3 & 2,0 & 10,6 \\
\hline MA & 1 & 0,7 & 11,3 \\
\hline MG & 18 & 11,9 & 23,2 \\
\hline MS & 4 & 2,6 & 25,8 \\
\hline MT & 3 & 2,0 & 27,8 \\
\hline PA & 9 & 6,0 & 33,8 \\
\hline PB & 6 & 4,0 & 37,7 \\
\hline PE & 20 & 13,2 & 51,0 \\
\hline $\mathrm{PI}$ & 12 & 7,9 & 58,9 \\
\hline PR & 4 & 2,6 & 61,6 \\
\hline RJ & 8 & 5,3 & 66,9 \\
\hline RN & 8 & 5,3 & 72,2 \\
\hline $\mathrm{RO}$ & 2 & 1,3 & 73,5 \\
\hline SC & 15 & 9,9 & 83,4 \\
\hline SE & 4 & 2,6 & 86,1 \\
\hline SP & 11 & 7,3 & 93,4 \\
\hline TO & 10 & 6,6 & 100,0 \\
\hline Total & 151 & 100,0 & \\
\hline
\end{tabular}

A primeira consideração a ser feita é a falta das seguintes unidades da federação compondo a tabela: Acre, Distrito Federal, Rio Grande do Sul e Roraima. No caso do Distrito Federal a consulta retornou "resultado zero", não sendo surpresa levando em conta que o Distrito Federal concentra competências estaduais e municipais e é objeto de eleições gerais. Quanto às demais unidades federativas, na data da consulta estavam sem comunicação com o sistema de pesquisa o que não pode ser interpretado como ausência de casos de abuso de poder nas respectivas eleições municipais.

Outro ponto a se destacar é o número de casos nos Estados de Minas Gerais e Pernambuco, $11,9 \%$ e $13,2 \%$, respectivamente. O fato de Minas Gerais ser o Estado com maior número de municípios no país pode ser o fator determinante para tal resultado. Pernambuco, por sua vez, representa um ponto fora de curva, inicialmente imaginamos tratar-se de uma ação conjunta do Ministério Público Eleitoral, mas a escrutínio dos dados revelou que são os próprios competidores eleitorais (candidatos, coligações e partidos) os principais recorrentes.

No que se refere ao número de casos de acordo com o recorte temporal proposto para este artigo, nota-se um forte incremento no número de recursos julgados e por consequência de ações judiciais como um todo a partir de $2008,69,5 \%$ dos casos concentram-se nas duas últimas eleições municipais, como se observa na tabela 2. Os resultados relativos às eleições locais extemporâneas não repercutem na série histórica utilizada neste artigo. Em que pese a leitura sugerir que o número de recursos está diretamente ligado ao aumento das ocorrências de abuso de poder nas eleições muni- 
cipais, ao relacionar esses números com as recorrências (tabela 3) e o grau de reconhecimento de abuso de poder (tabela 5) percebe-se "um maior know-how" dos atores políticos e uma maior eficiência na análise e registro dos julgados pela Justiça Eleitoral.

\section{Tabela 2: Decisões dos TREs referentes} ao abuso de poder por eleição

\begin{tabular}{|l|c|c|c|}
\hline & Frequência & \% & \% Acumulado \\
\hline Missing & 19 & 11,9 & 11,9 \\
\hline 1996 & 8 & 5,3 & 17,1 \\
\hline 2000 & 9 & 6,0 & 23,1 \\
\hline 2003 & 1 & 0,7 & 23,8 \\
\hline 2004 & 7 & 4,6 & 28,4 \\
\hline 2008 & 48 & 31,8 & 60,2 \\
\hline 2010 & 2 & 1,3 & 62,3 \\
\hline 2012 & 57 & 37,7 & 100,0 \\
\hline Total & 151 & 100,0 & \\
\hline
\end{tabular}

Durante o levantamento dos dados nos casos em que houve pluralidade de recorrentes e quando vencedor e vencido no processo recorreram, adotamos como parâmetro o primeiro recorrente apontado e quem primeiro recorreu. Ao longo desse artigo classificamos os atores eleitorais conforme sua ação racional em duas categorias, competidores eleitorais e reguladores eleitorais. A tabela 3 evidencia que os competidores eleitorais constituem a maior categoria de recorrentes nos casos de abuso de poder nas eleições municipais. Estão presentes como recorrentes em $75,5 \%$ dos casos, assim distribuídos: candidatos $34,4 \%$, coligações $28,5 \%$ e partidos $12,6 \%$.

Tabela 3: Número de processos por tipo de Recorrente

\begin{tabular}{lccc}
\hline \hline & Frequência & $\%$ & \% Acumulado \\
\hline Missing & 3 & 2,0 & 2,0 \\
\hline Candidato & 52 & 34,4 & 36,4 \\
\hline Coligação & 43 & 28,5 & 64,9 \\
\hline Ministério Público & 17 & 11,3 & 76,2 \\
\hline
\end{tabular}

\begin{tabular}{lccc}
\hline Outros & 17 & 11,3 & 87,4 \\
\hline Partido & 19 & 12,6 & 100,0 \\
\hline Total & 151 & 100,0 & \\
\hline \hline
\end{tabular}

Tais evidências apontadas pela pesquisa, quanto aos atores recorrentes dos pleitos, se assemelham aos achados de Vitor Marchetti (2014, p.101), no que se refere ao questionamento das práticas de campanha pelos competidores eleitorais. Os dados encontrados pelo autor, referente ao período da sua pesquisa, apontaram que 58\% dos recursos eleitorais foram oriundos dos próprios atores políticos envolvidos na disputa; e na sequência, o Ministério Público.

Nos casos de abuso, observados na tabela 4, tem-se que os atos abusivos são apresentados à Justiça Eleitoral ora de maneira isolada, especificando de qual abuso se trata (64,9\% dos casos analisados), ora deduzindo ambas as espécies de abuso na mesma ação (31,1\% dos casos). Nota-se também que os casos de abuso de poder econômico são a maioria, tomados isoladamente perfazem $40,4 \%$ dos casos, acrescentando-Ihe os casos em que foi deduzido em conjunto com abuso de poder político, chegamos a $71,5 \%$ dos casos.

Tabela 4: Apresentacão isolada ou cumulada do abuso à Justiça Eleitoral.

\begin{tabular}{|l|c|c|c|}
\hline & Frequência & $\%$ & \% Acumulado \\
\hline Missing & 6 & 3,3 & 3,3 \\
\hline Ambos & 47 & 31,1 & 34,4 \\
\hline $\begin{array}{l}\text { Econômi- } \\
\text { co }\end{array}$ & 61 & 40,4 & 74,8 \\
\hline Político & 37 & 24,5 & 100,0 \\
\hline Total & 151 & 100,0 & \\
\hline
\end{tabular}

$\mathrm{Na}$ análise dos dados da tabela 5 percebese uma forte tendência nos Tribunais Regio- 
nais Eleitorais em não reconhecer o abuso de poder. Tal resultado pode ser sugestivo da "cautela" que as Cortes Eleitorais têm em proferir decisões que podem alterar os resultados dos pleitos, existe a possibilidade, ainda, do manejo sem critérios de ações e recursos pelos competidores eleitorais, fazendo com que pretensões de reconhecimento de abuso mal formuladas ou "forçadas" sejam rechaçadas pelos Tribunais.

Tabela 5: Reconhecimento do abuso de poder em eleições municipais

\begin{tabular}{lccc}
\hline \hline & Frequência & \% & \% Acumulado \\
Não & 102 & 67,5 & 67,5 \\
Sim & 49 & 32,5 & 100,0 \\
Total & 151 & 100,0 & \\
\hline \hline
\end{tabular}

Também é possível identificar que as decisões da $1^{a}$ Instância eleitoral são, via de regra, prestigiadas pelos respectivos Tribunais Eleitorais. Os dados da tabela 6 evidenciam que $44,4 \%$ das decisões de $1^{a}$ Instância são mantidas na totalidade e 15,9\% mantidas em parte. A tabela 7 representa a modificação da decisão de $1^{a}$ Instância e o resultado final apresentado pelo TRE. Nela é possível notar que as decisões de $1^{a}$ Instância são frequentemente mantidas quando o Tribunal, ao final, nega a existência do abuso (48 casos), portanto, neste dado a $1^{\text {a }}$ Instância (o juiz eleitoral) entendeu pela inexistência do abuso de poder na eleição municipal e a $2^{a}$ Instância (TRE) manteve o entendimento.

Todavia, quando o dado revela que as decisões de $1^{\text {a }}$ Instância foram modificadas e o Tribunal, ao final, entende pela inexistência do abuso, estamos diante de uma decisão de $1^{a}$ Instancia que reconheceu o abuso e o tribunal a modificou para negá-lo. Nestes casos ( $1^{a}$ Instância reconhece 0 abuso e $2^{a}$
Instância nega), temos alta incidência de modificações das decisões dos juízes eleitorais (37 casos). O que os dados revelam é a forte tendência dos TREs em negar a ocorrência do abuso de poder em eleições locais. Quando a justiça eleitoral local também nega a ocorrência, suas decisões são mantidas, quando as reconhece, são modificadas.

Tabela 6: Alterações na decisão de $1^{\text {a }}$ Instância.

\begin{tabular}{|l|c|c|c|}
\hline & Frequência & $\%$ & \% Acumulado \\
\hline Mantida & 67 & 44,4 & 44,4 \\
\hline Mantida em Partes & 24 & 15,9 & 60,3 \\
\hline Modificada & 44 & 29,1 & 89,4 \\
\hline Não Analisada & 16 & 10,6 & 100,0 \\
\hline Total & 151 & 100,0 & \\
\hline
\end{tabular}

Tabela 7: Situação da decisão de $1^{\text {a }}$ Instância de acordo com decisão final dos Tribunais Regionais Eleitorais

\begin{tabular}{lcccc}
\hline \hline & Mantida & $\begin{array}{c}\text { Mantida } \\
\text { em Partes }\end{array}$ & Modificada & $\begin{array}{c}\text { Não } \\
\text { Analisada }\end{array}$ \\
Sim & 19 & 23 & 7 & 0 \\
\hline Não & 48 & 1 & 37 & 16 \\
Total & 67 & 24 & 44 & 16 \\
\hline \hline
\end{tabular}

Apesar da tendência de os Tribunais Regionais Eleitorais negarem o abuso de poder, há, entretanto, casos em que a justiça eleitoral se pronuncia pela incidência do abuso de poder nas eleições e, em consequência, aplica sanções correlatas. Nos casos em que houve pluralidade de punições aplicadas, consideramos a primeira punição que foi mencionada no julgamento. A tabela 8 apresenta as sanções aplicadas quando do reconhecimento do abuso pelo TRE. A grande incidência de casos "não se aplica" (76,8\%) está diretamente ligada a grande negativa no reconhecimento dos abusos (ver tabela 5). A tabela 9 representa um re- 
corte contendo somente os casos em que houve o reconhecimento de abuso de poder e a(s) sanção(ões) aplicada(s).

\section{Tabela 8: Tipo de sanção aplicada}

\begin{tabular}{|l|c|c|c|}
\hline & Frequência & $\%$ & \% Acumulado \\
\hline Missing & 1 & 0,7 & 0,7 \\
\hline $\begin{array}{l}\text { Cassação do } \\
\text { Diploma }\end{array}$ & 12 & 7,9 & 8,6 \\
\hline Inelegibilidade & 12 & 7,9 & 16,6 \\
\hline Multa & 6 & 4,0 & 20,5 \\
\hline Não se Aplica & 116 & 76,8 & 97,4 \\
\hline Outros & 4 & 2,6 & 100,0 \\
\hline Total & 151 & 100,0 & \\
\hline
\end{tabular}

Tabela 9 - Espécie de abuso de poder e sanção aplicada

\begin{tabular}{lcccc}
\hline \hline & $\begin{array}{c}\text { Cassação } \\
\text { do } \\
\text { Diploma }\end{array}$ & Inelegibilidade & Multa & Outros \\
Político & 3 & 4 & 3 & 2 \\
\hline Econômico & 4 & 4 & 1 & 2 \\
Ambos & 5 & 4 & 2 & 0 \\
\hline \hline
\end{tabular}

Até aqui apresentamos os dados agregados, representando um painel nacional sobre o tratamento do abuso de poder nas eleições municipais pelos Tribunais Regionais Eleitorais, a seguir os dados serão tratados de forma regionalizada.

\subsection{APRESENTAÇÃO DOS DADOS REGIONALIZADOS}

Os dados foram tabulados regionalmente. O primeiro recorte feito diz respeito ao número de casos por região, dando origem ao gráfico 1. É fácil perceber que nas regiões em que há maior número de eleitores (Sudeste e Nordeste) existe maior incidência de casos levados aos Tribunais. O número de casos na região Sul pode ter sido impactado pela ausência de comunicação entre a base de dados do TRE-RS e o sistema de pesquisa do TSE quando da coleta dos dados.

\section{Gráfico 1: Processos por região geográfica}

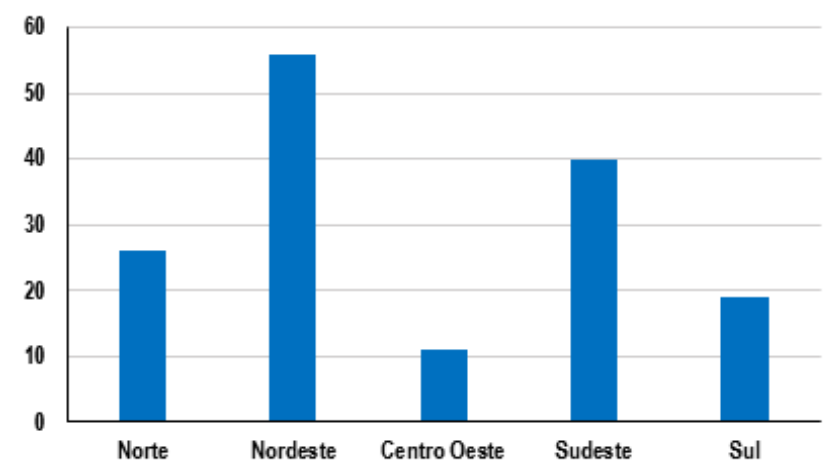

Através do gráfico 2 os dados foram desmembrados conforme o reconhecimento do abuso ou não. É possível notar que o não reconhecimento do abuso de poder pelos Tribunais Regionais Eleitorais tem maior ocorrência, preponderando em quase todas as regiões, a exceção ocorre no Centro Oeste. Embora o número absoluto de casos seja baixo, o dado é relevante, pois a região Centro Oeste combina baixo número de unidades da federação e baixa concentração populacional. A região Norte se destaca pela grande desproporção entre as decisões que reconhecem e as que negam o abuso de poder.

\section{Gráfico 2: Reconhecimento de abuso por região geográfica}

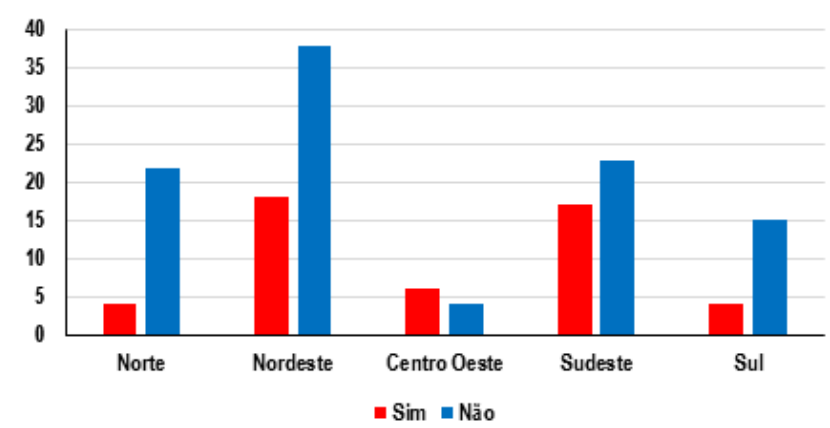


O fator tempo é relevante na análise do funcionamento do Judiciário. Na Justiça Eleitoral o tempo avulta em importância dada a periodicidade das eleições e sua alternância (nacionais e locais) a cada dois anos. O gráfico 3 apresenta esse tempo, em anos contados da eleição em que ocorreu a alegação de abuso de poder até que o Tribunal tenha proferido uma decisão".

Gráfico 3: Tempo médio em anos entre a eleição e o acórdão

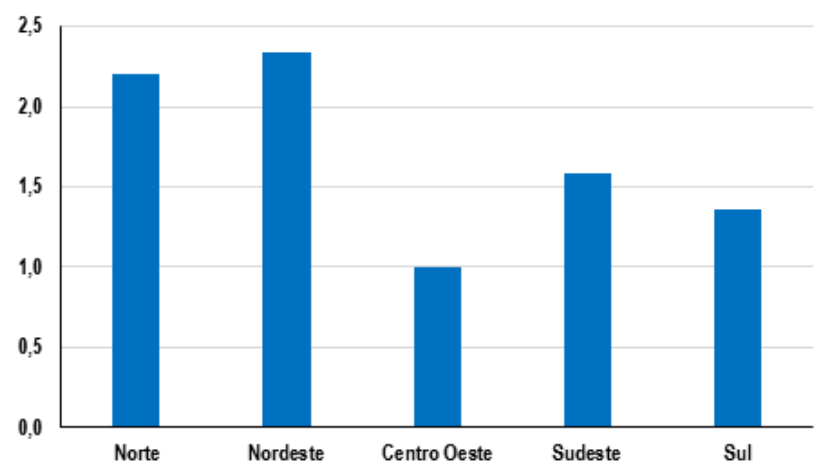

A tabela 10 foi elabora levando em conta cada tipo de recorrente discriminado por região em números absolutos. A regionalização dos dados reflete o que já foi observado nos dados agregados. Temos uma preponderância de recursos pelos competidores eleitorais em todas as unidades da federação com destaque para os candidatos e coligações nas eleições locais. Na região Sudeste temos um número pouco maior de recursos por partidos políticos.No entanto, mesmo nessa região, o papel dos partidos enquanto homologadores de recursos junto aos tribunais acaba ficando em segundo plano em relação aos candidatos e às coligações, que podem ser vistos como os grandes atores recursais eleitorais. Tais questões se colocam à margem do que autores como

11 É importante ressaltar que não se trata no tempo de demora no processo contado do seu início, e sim quanto tempo levou para que um TRE se pronunciasse através de acórdão sobre abuso de poder em eleição municipal contado da data da referida eleição.
Katz e Mair (2001) atribuem como sendo o papel essencial dos partidos políticos para a estabilidade política e democrática. E se reforçam com uma forte indisposição no que se refere à representatividade e ao ideário dos partidos políticos. A desconfiança acaba sendo o mote central entre grande parte das pessoas, o que reforça a crise que os partidos vêm enfrentando (Baquero, Castro, \& Ranincheski, 2016).

O regulador eleitoral com legitimidade para tais recursos, o Ministério Público Eleitoral, apresenta também papel secundário em levar questões de abuso de poder em eleições municipais aos TREs. Em relação ao MPE merece destaque o fato de que na região Sul não foram contabilizados recursos propostos pela instituição.

Tabela 10: Tipo de recorrente por região geográfica

\begin{tabular}{|l|c|c|c|c|c|}
\hline & Norte & Nordeste & $\begin{array}{c}\text { Centro } \\
\text { Oeste }\end{array}$ & Sudeste & Sul \\
\hline Missing & 0 & 1 & 0 & 0 & 2 \\
\hline Candidato & 10 & 22 & 2 & 12 & 6 \\
\hline Coligação & 5 & 15 & 4 & 13 & 6 \\
\hline $\begin{array}{l}\text { Ministério } \\
\text { Público }\end{array}$ & 4 & 7 & 2 & 4 & 0 \\
\hline Outros & 3 & 8 & 0 & 5 & 1 \\
\hline Partido & 4 & 3 & 2 & 6 & 4 \\
\hline Total & 26 & 56 & 10 & 40 & 19 \\
\hline \hline
\end{tabular}

A regionalização dos dados referentes à espécie de abuso (tabela 11) não se desvia, em regra, dos dados agregados. Há predominância do abuso de poder econômico em quase todas as regiões. Entretanto, foi possível notar que na região Centro Oeste houve um maior número de casos de abuso de poder político em relação aos de abuso de poder econômico por pequena margem. Nas regiões Nordeste e Sudeste percebe-se que 
a alegação de ambos os abusos na mesma ação é quase tão frequente quanto a alegação isolada do abuso de poder econômico.

Tabela 11 - Espécie de abuso por região geográfica

\begin{tabular}{|l|c|c|c|c|c|}
\hline & Norte & Nordeste & $\begin{array}{c}\text { Centro } \\
\text { Oeste }\end{array}$ & Sudeste & Sul \\
\hline Missing & 3 & 0 & 1 & 1 & 1 \\
\hline Ambos & 6 & 21 & 1 & 16 & 3 \\
\hline Econômico & 10 & 22 & 3 & 19 & 7 \\
\hline Político & 7 & 13 & 5 & 4 & 8 \\
\hline Total & 26 & 56 & 10 & 40 & 19 \\
\hline
\end{tabular}

Ao analisar o "prestígio" das decisões dos juízes eleitorais (tabela 12) pelos respectivos TREs (se houve manutenção ou modificação da decisão) mais uma vez a região Sul é a única que se afasta dos dados agregados, apresentando um maior grau de modificação do que de manutenção das decisões de $\eta^{a}$ Instância.

Tabela 12: Alterações na decisão de primeira instâncía por região geográfica

\begin{tabular}{|l|c|c|c|c|c|}
\hline & Norte & Nordeste & $\begin{array}{c}\text { Centro } \\
\text { Oeste }\end{array}$ & Sudeste & Sul \\
\hline Missing & 0 & 0 & 0 & 0 & 0 \\
\hline Mantida & 12 & 21 & 4 & 24 & 6 \\
\hline $\begin{array}{l}\text { Mantida em } \\
\text { Partes }\end{array}$ & 3 & 12 & 3 & 5 & 1 \\
\hline Modificada & 9 & 15 & 2 & 8 & 10 \\
\hline Não Analisada & 2 & 8 & 1 & 3 & 2 \\
\hline Total & 26 & 56 & 10 & 40 & 19 \\
\hline
\end{tabular}

$\mathrm{Na}$ análise dos dados regionais quanto ao tipo de sanção aplicada, temos variação por região no que se refere à sanção mais frequente. A cassação do diploma e a multa têm maior incidência na região Nordeste, a inelegibilidade ocorreu com maior frequência no Sudeste. As regiões Norte e Sul se destacam pela baixa incidência de san- ções aplicadas. O Sul apresenta apenas dois casos de inelegibilidade e o Norte um caso de cassação de diploma e outro de multa. O Centro Oeste não apresenta destaques, refletindo apenas os dados agregados. A tabela 13 apresenta os valores absolutos.

Tabela 13 - Tipo de sanção aplicada por região geográfica

\begin{tabular}{|l|c|c|c|c|c|}
\hline & Norte & Nordeste & $\begin{array}{c}\text { Centro } \\
\text { Oeste }\end{array}$ & Sudeste & Sul \\
\hline Missing & 0 & 1 & 0 & 0 & 0 \\
\hline $\begin{array}{l}\text { Cassação do } \\
\text { Diploma }\end{array}$ & 1 & 7 & 1 & 3 & 0 \\
\hline Inelegibilidade & 0 & 2 & 3 & 5 & 2 \\
\hline Multa & 1 & 3 & 1 & 1 & 0 \\
\hline Não se Aplica & 23 & 40 & 5 & 31 & 17 \\
\hline Outros & 1 & 3 & 0 & 0 & 0 \\
\hline Total & 26 & 56 & 11 & 40 & 19 \\
\hline
\end{tabular}

Por fim, tem-se que a ausência de parâmetros rígidos para definição do abuso de poder tende a esvaziar a credibilidade do Poder Judiciário eleitoral e de sua atuação, uma vez que em meio a soluções casuísticas não raro encontram-se decisões conflitantes. A necessidade de tais soluções pode ser entendida como uma das possíveis causas do assoberbamento de processos na justiça eleitoral brasileira. Por não saber ao certo se a conduta é abusiva ou não, na dúvida, opta-se em acionar a máquina judicial para que ela diga ao fim se houve ou não abuso de poder.

\section{CONSIDERAÇÕES FINAIS}

A organização da Justiça Eleitoral possui peculiaridade que a individualiza e impede comparações exatas com outros aparelhos judiciários existentes no Brasil. Ela tem um quadro próprio de servidores públicos, mas não possui um quando próprio de Magistrados. Em certa medida justifica-se pela 
realização de eleições somente a cada dois anos e pelo risco de uma instituição se assenhorar do processo político impedindo ou manipulando a liberdade democrática e a soberania popular para atender visões políticas próprias. Por outro lado, em especial nos órgãos colegiados (TSE e TREs) a investidura por tempo determinado dificulta sobremaneira a formação de uma jurisprudência estável sobre os temas eleitorais. Essa característica tende a provocar insegurança jurídica nos atores eleitorais e atinge o tema do abuso de poder nas eleições.

O abuso de poder em matéria eleitoral padece de conceituação e sistematização legislativa. Diante da lacuna legislativa autores jurídicos propõem conceitos próprios e mesmo a Justiça Eleitoral possui um glossário para consulta pública na internet ${ }^{12} \mathrm{com}$ isso pretendendo dicionarizar a expressão. Uma outra vertente procura enumerar casos exemplificativos de abuso de poder em eleições. Porém, ainda não há um estudo das fontes que originaram a noção de abuso de poder eleitoral. Vale ressaltar que a formulação jurídica do abuso de poder eleitoral inicia-se com a teoria do abuso de direito, construída no direito civil e, posteriormente, complementada pela teoria do abuso de poder construída no direito administrativo. Cada um desses pilares serve de sustentação ao que se entende como abuso de poder econômico e abuso de poder político na seara eleitoral.

Diante de um conceito jurídico indeterminado, faz-se necessário ter em perspectiva que ao tratarmos de abuso de poder eleitoral teremos a extrapolação do espaço de licitude previsto na norma. A percepção dos fins previstos na lei é relevante por mais fluída que pareça a ideia. O abuso de poder é

12 Ver em: http://www.tse.jus.br/eleitor/glossario. identificado diante de casos concretos, de modo casuístico e para tanto a interpretação dada pelos órgãos judiciários é extremamente relevante, principalmente em razão da regra interpretativa contida no art. 23 da LC 64/9013. Na interpretação do caso concreto e na sua confrontação com o espaço de licitude contido na norma o aplicador da lei precisa ter olhos na realidade que o cerca.

O desdobramento empírico deste artigo esbarrou na consulta dos dados. A base para consulta pública disponibilizada pelo TSE merece aperfeiçoamentos. Não há integração dos TREs ao sistema de pesquisa do TSE de modo estável. A falta de parametrização para o uso de palavras-chave na base de dados de julgados do TSE representa um risco de vieses caso o pesquisador não seja familiarizado com a rotina forense e o funcionamento da justiça eleitoral. Além do fato de que os acervos das decisões dos Tribunais Eleitorais não estão digitalizados no seu inteiro teor dos acórdãos. Tem-se apenas disponibilizadas as ementas do que foi decidido.

O número de recursos apreciados e decididos pelos TREs aumentou fortemente nas últimas eleições municipais, analisadas neste artigo até o pleito municipal de 2012. Embora seja possível fazer a leitura de um maior número de casos de abuso de poder, quando temos ol hos no que foi efetivamente decidido nos Tribunais,a hipótese cai por terra. Apesar da inexistência de efeitos vinculantes e de uma rígida padronização no exercício das funções administrativas e judiciais entre os diversos Tribunais Regionais, ao realizar o levantamento dos dados contatamos uma uniformidade de práticas. Via de regra os Tribunais Regionais Eleitorais

13 Art. 23. O Tribunal formará sua convicção pela livre apreciação dos fatos públicos e notórios, dos indícios e presunções e prova produzida atentando para circunstâncias ou fatos, ainda que não indicados ou alegados pelas partes, mas que preservem o interesse público de lisura eleitoral. 
negam a existência de abuso de poder nas eleições municipais. O prestígio das decisões de $1^{a}$ Instância (confirmação das decisões dos juízes eleitorais) está diretamente ligado ao não reconhecimento da prática de abuso de poder.

Os atores eleitorais mais ativos em apresentar recursos aos TREs são os competidores eleitorais com grande predominância de candidatos e coligações. A maior incidência de recursos encaminhados aos Tribunais Eleitorais, por sua vez, ocorre nas regiões com maior número de eleitores Sudeste e Nordeste. Em matéria de litígios eleitorais envolvendo abuso de poder em eleições locais apresentados à $2^{a}$ Instância o que importa são os competidores diretamente envolvidos na disputa, quando se nota- o interesse em alterar o resultado das urnas através de decisões judiciais, o que pode representar uma indesejada judicialização do processo eleitoral.

O aparelho legal e judiciário é reflexo dos valores e das práticas existentes no meio social. No Brasil, infelizmente, temos uma série de valores consagrados relativos à lisura do processo eleitoral que não corresponde à prática das eleições. O arcabouço legislativo vem sendo construído lentamente passando por alterações legislativas pontuais para seu aperfeiçoamento. A própria instituição de uma "Justiça" como agência reguladora de eleições pode ser vista como uma exortação para que a disputa eleitoral ocorra com lisura e ao largo das paixões típicas da política. A história republicana do Brasil pode ser lida em termos de uma busca por um processo de escolha política livre de vícios e que garanta ao eleitor o exercício do direito de voto livre de abusos e constrangimentos. E deste modo, garantindo que eventual alteração da decisão popular através do voto seja sempre exceção, jamais regra. Nessa perspectiva temos um longo caminho para consolidação e amadurecimento de nossas instituições e fortalecimento de nossa democracia.

\section{REFERÊNCIAS}

Abdo, H. N. (2007). O abuso do processo. Coleção Estudos de Direito de Processo Enrico Tullio Liebman. São Paulo: Revista Tribunais,.vol. 60, São Paulo.

Almeida, R.R. (2018). Financiamento eleitoral e ética empresarial: a participação das empresas no processo eleitoral. In.: Anais do V Congresso Luso-Brasileiro de Direitos Humanos, vol.03, n²6, Curitiba, 2018. pp. 292-313

Amaral, F. (2006). Direito civil: Introdução.6a ed. Rio de Janeiro: Renovar.

Arantes, R. B. \& Kerche, F. (1999). Judiciário e democracia no Brasil. Novos Estudos CEBRAP, São Paulo, n. 54, p.11-26.

Avritzer, L.(2013). Judicialização da política e equilíbrio de poderes no Brasil. .In:Avritzer, L.; Bignotto, N.; Filgueiras, F.et al. (orgs.).Dimensões políticas da justiça. Rio de Janeiro: Civilização Brasileira.

Bandeira De Mello, C. A. (2000).Discricionariedade e controle judicial. $2^{a}$ ed.São Paulo: Malheiros.

Bandeira De Mello, O. A. (1969). Princípios gerais de direito administrativo. Rio de Janeiro: Forense.

Baquero, M.; Castro, H. C.; e Ranincheski, S. M. (2016). (Des)confiança nas instituições e partidos políticos na constituição de uma democracia inercial no Brasil: o caso das eleições de 2014. Revista Política \& Sociedade. Florianópolis,v.15, n.32, pp.9-38.

Barros, F. D.(2012). Direito eleitoral. $11^{\mathrm{a}}$ ed .Rio de Janeiro: Elsevier.

Barroso, L. R., 2008. Judicialização, ativismo judicial e legitimidade democrática. Disponível em: <http:// www.conjur.com.br/2008-dez-22/judicializacao_ativismo_legitimidade_democratica > Acesso em: 02/11/2015.

Batista, F. N. T.; Peleja Jr., A. V.(2012). Direito Eleitoral, Aspectos processuais: Ações e Recursos.2 $2^{a}$. ed. Curitiba: Juruá.

Beviláqua, C.(1976). Teoria geral do direito civil. Rio de Janeiro: Ed. Francisco Alves. 
Capeller, W. (2015). De que Lugar Falamos? Retomando um velho papo sobre o Direito e a Sociologia. Revista de Estudos Empíricos em Direito - Brazilian Journal of Empirical Legal Studies. vol. 2, n. 2, p.10-25.

Carvalho, E. (2009). Judicialização da política no Brasil: controlo de constitucionalidade e racionalidade política. Revista Análise Social, vol. XLIV (191), pp.315-335. Castro, E. R.(2012). Curso de Direito Eleitoral. Belo Horizonte: Ed. Del Rey.

Costa, A. S.(2006). Instituições de direito eleitoral. $6^{\mathrm{a}}$ ed. Belo Horizonte: Del Rey.

D'Azevedo, L.C. (2016). Abuso de poder na eleições municipais brasileiras em perspectiva comparada: Uma análise das decisões dos tribunais regionais eleitorais. Dissertação de conclusão de mestrado em Sociologia Política. UENF. Campos dos Goytacazes/RJ.

Di Pietro, M. S. Z.(2003). Direito administrativo. $15^{\mathrm{a}}$ ed São Paulo: Atlas.

Figueiredo Filho, D. B. (2005). Gastos Eleitorais: os determinantes das eleições? Estimando os gastos de campanha nas eleições de 2002.Revista Urutagua (Online).Maringá, v.8, p.1-10.

Filgueiras Jr., M. V.(2007). Conceitos jurídicos indeterminados e discricionariedade administrativa. Rio de Janeiro: Lumen Juris.

Gomes, J. J.(2012). Direito Eleitoral. $8^{a}$ ed São Paulo: Atlas.

Gonçalves, G. L. (2011). Entre politização e judicialização: limites estruturais do direito e da política.In:Motta, L. E.; e Mota, M. (orgs.).O estado democrático de direito em questão. Rio de Janeiro: Elsevier.

Graeff, C.B.; Barreto, A.A. de B. (2017). O modelo de governança eleitoral brasileiro e a judicialização das regras político-eleitorais. In.Revista Debates, Porto Alegre, v. 11, n. 1, p. 99-118, jan.-abr. 2017.

Heiler, J.G. (2018). O Fenômeno da Reiteração no Financiamento Eleitoral Brasileiro: perfil de financiadores e o impacto no desempenho eleitoral empresarial. Tese de doutorado em Ciência Política/UNICAMP. Campinas.

Jorge, A. G. L., \& Soares, M. B. (2017). Financiamento eleitoral por pessoas jurídicas: a influência do poder econômico sobre a democracia. Revista de Informação Legislativa: RIL, 54(216), 87-104. Recuperado de http://www12.senado.leg.br/ril/edicoes/54/216/ ril_v54_ n216_p87.

Jorge, A.G.L. \& Lizardo, F.S. (2018). Financiamento de Campanhas e o Artigo 30-A da Lei das Eleições na Proteção à Igualdade no Processo Eleitoral. Cap.2. Parte II.
Fraude, Corrupção e os Diferentes Abusos Eleitorais. In: Fux, L.; Pereira, L.F.C.; \& Agra, W. M. (Coord.); Peccinin, L.E. (Org.). Abuso de Poder e Perda de Mandato. Belo Horizonte: Fórum.

Katz, R.; Mair, P. (2002). The ascendancy of the party in public office: party organizational change in twentieth-century democracies. In: Gunther, R.; Montero, J. R.; Linz, J. (Eds). Political Parties: Old Concepts and New Challenges. Oxford: Oxford University Press.

Konder, A.; Inatomi, C. C.; Baratto, M. (2011). Sobre o judiciário e a judicialização.In:Meirelles, H. L. Direito administrativo brasileiro.38 ${ }^{a}$ ed. São Paulo: Malheiros. Mancuso, W. P. (2015). Investimento eleitoral no Brasil: balanço da literatura (2001-2012) e agenda de pesquisa. Revista de Sociologia Política, v. 23, n. 54, p. 155-183. Marchetti, V. \& Cortez, R.(2009). A judicialização da competição política: o TSE e as coligações eleitorais. Revista Opinião Pública, vol. 15, n² 2, p.422-450.

Marchetti, V. (2014). Competição eleitoral e controle das candidaturas: uma análise das decisões do TSE. Cadernos Adenauer XV. n¹, p.93-115.

Motta, L. E. (2011). Judicialização da política e representação funcional no Brasil contemporâneo: uma ameaça à soberania popular?, In:Motta, L. E.; e Mota, M. (orgs.). $\mathrm{O}$ estado democrático de direito em questão. Rio de Janeiro: Elsevier.

Peixinho, M. M.(2008). Princípio da separação dos poderes, a judicialização da política e direitos fundamentais. In:Revista de Direitos e Garantias Fundamentais, Vitória, n. 4, p.13-44. Disponível em: <http://www.fdv. $\mathrm{br} / \mathrm{sisbib/index.php/direitosegarantias/article/view/3>}$ Acesso em: 04/11/2014.

Peixoto, V. M. (2009). Financiamento de campanhas: o Brasil em perspectiva comparada. Perspectivas: Revista de Ciências Sociais.UNESP. Araraquara,v. 35, p. 91-116.

Pereira, C. M. S.(1998). Instituições de direito civil, introdução ao direito civil, teoria geral do direito civil. 19ª ed . Rio de Janeiro: Forense.

Pogrebinschi, T.(2011). Judicialização ou representação? Política, direito e democracia no Brasil. Rio de Janeiro: Elsevier

Quintaneiro, T.; Barbosa, M. L. O.; e Oliveira, M. G. M. (2003). Um Toque de Clássicos Marx, Durkheim e Weber. $2^{a}$ ed .Belo Horizonte: Ed. UFMG.

Reale, M. (2009). Lições preliminares de direito. $27^{a}$ ed. São Paulo: Saraiva.

Rodovalho, T. (2011). Abuso de direito e direitos subjetivos. São Paulo: Revista dos Tribunais. 
Rosas, R.(2011). Do abuso de direito ao abuso de poder. São Paulo: Malheiros Eds.

Sadek, M. T. Judiciário: mudanças e reformas. Estudos Avançados. vol.18, n.51. p.79-101. Disponível em: <http://www.scielo.br/scielo.php?pi$d=$ S0103-40142004000200005\&script=sci_arttext $>$ Acesso em: 13/10/2012.

Schedler, A. (1999), Conceptualizing Accountability. In: Schedler, A.; Diamond, L. \& Plattner, M.F. The Self-Restraining State: power and accountability in new democracy. Bouder. Lynne Rtnner Publishers.

Silva, A. (2012). Ações eleitorais: teoria e prática.Leme: Ed. J.H. Mizuno.

Sobreiro Neto, A. (2018). O Papel do Ministério Público Eleitoral na Repressão dos Abusos nas Eleições.In: Fux, L.; Pereira, L.F.C.; \& Agra, W. M. (Coord.); Peccinin, L.E. (Org.). Abuso de Poder e Perda de Mandato. Belo Horizonte: Fórum.

Souza, L.F. (2017). Jurisprudência eleitoral e soberania popular: Legitimidade de cassação nas ações eleitorais (AIME e RCED)..Rev. Ciênc. Juríd. Soc. UNIPAR, v. 20, n. 1, p. 73-87.

Speck, B. W. (2002). Como financiar a competição política? Concepções contemporâneas, ilustrações do caso da Alemanha e perspectivas para a situação em Uruguay. Dinero y Politica. El financiamento de los Partidos en la Democracia. Montevideo: La Banda Oriental. pp. 15-41.

Stoco, R. (2002).Abuso do direito e má-fé processual. São Paulo: Revista dos Tribunais.

Strücker, B.; Maçalai, G. (2019). O abuso de poder religioso no processo eleitoral: Realidades brasileiras e soluções. Coisas do Gênero. vol. 5, n. 1. pp. 87-100. São Leopoldo.Disponível em: http://periodicos.est.edu.br/ index.php/genero.

Weber, M.(2005).Ciência e política: duas vocações.13a ed. São Paulo: Cultrix.

Yamaguti Sato, L.T. (2018). As Regras de Comportamento Impostas aos Agentes Públicos em Período Eleitoral: das condutas vedadas ao abuso de poder político. In: Fux, L.; Pereira, L.F.C.; \& Agra, W. M. (Coord.); Peccinin, L.E. (Org.). Abuso de Poder e Perda de Mandato. Belo Horizonte: Fórum.

Data de submissão: 08/06/2018

Data de aceite: 19/07/2019 